\title{
Extend Building Life and Promote Building Energy Efficiency
}

\author{
Deqin Cuil, a Qingzhong Yang ${ }^{2, b}$
}

\author{
${ }^{1}$ Jilin Agriculture Science and Technology College, Institute of machinery and construction, \\ department of architecture, Jilin, China 132101; ${ }^{2}$ Jilin Agriculture Science and Technology College, \\ School of economics and management, Jilin, China 132101
}

a274773191@qq.com, byyzzqq@163.com,

Keywords: Building Life; Waste; Quality; Regulation

Abstract: Building "short-lived" phenomenon is very common in China. It is extremely wasteful for a developing country with limited resources and financial resources (per capita). Any green low carbon, energy saving and environmental protection without building safety would like water without a source, and a tree without roots. Extending the building life, based on Chinese current situation, mainly starts out here from two aspects of new buildings and the existing buildings, and need strengthen government regulation. Fundamentally extend building life and promote building energy efficiency.

\section{The current situation of building life in China}

TongYuezhong, the deputy director of housing industrialization promotion center, the ministry of construction once said, "The domestic residential average life expectancy is only for 30 years." However, 《Design of civil buildings 》 in China has set rules: The endurance life for important buildings and the main structure of high-rise buildings is 100 years, the general building for 50-100. Construction actual life and the general design principles in our country still have quite a distance. Not only the civilian residential building life is short, but some commercial service building such as Qingdao hotel is short-lived as well. In addition, bridge in the outdoor durability is more concerning. For reinforced concrete Bridges in service, the phenomenon such as steel corrosion and concrete cracking is very widespread. For example, Beijing's Xizhimen overpass earliest built in china was forced to dismantle because of quality problem. The using period was less than 19 years. Overpasses in Tianjin zhonghuan road, after running more than 10 years, were established for overhaul or partly replaced. The head of the ministry of construction in the 6th international conference on green building and building energy conservation said: "The new buildings quantity every year in China is the largest, but these buildings only last 25 to 30 years."

Building "short-lived" caused a great waste of resources and environmental pollution. A building frequently costs tens or even hundreds of millions yuan, requires a lot of precious resources, also need a large number of human toil day and night. If it is dismantled, all inputs would go to waste, and increased a lot of construction waste hard to deal with.

Compared with the "short-lived" building in China, building in some countries has very long life. According to statistics, the average residential life in Europe is 80 years, Britain building has the maximum life, 132. Germany is 66 because of world war two. Urban residential life below 50 years is quite common. In the UK, "centennial houses" can be seen everywhere. Because the construction quality is highly valued, planning, design has also been demonstrated in detail. At the same time, they also pay attention to the maintenance, reinforcement and disease treatment of the buildings to extend the building life and improve the utilization efficiency of resources. In China, a house built in the 70s, most have been demolished. Now houses built in the 80 s have been begun. A building was designed for using 70 years, if only using 20 30years was demolished, it is undoubtedly a huge waste of resources. 


\section{The understanding of building life}

The concept of the durability (life) of buildings was known in the early 1990s, when some of the building scientific experts in China went abroad to visit. Foreign construction industry attaches great importance to study the durability of structures. A building also has its structure, working cultural and commercial life. Starting from its design, building has entered its circulation process.

\section{Structure life of the building}

Structure life standard of China building: safety, applicable and durability. 《Reliability design unified standard for building structures $》$ in our country sets rules for the ordinary housing life for 50 years, important building for 100. Structure life is for the safety, applicability and durability of building structures. Building structure is like a skeleton of the individual, including base, slab, beam, column and other components to support the whole building. If something goes wrong in this period, it must be wrong in design, construction, use and maintenance of a link. When building reached age limit, it doesn't immediately go wrong. Perhaps the structure failure probability relatively increased. The building also can prolong life through the inspection, appraisal and reinforcement transformation.

\section{Working life of the building}

《Design of civil buildings 》 in China has set rules: There is the same corresponding relationship between structure and working life. But we referred that working life has a broader meaning. Because the building itself has the flexibility, elasticity, and pliability of function changes and use requirement, using content in a house can be changed. The examples that building completely changed use function after the modification are common.

\section{Cultural life of the building}

Cultural life of the building focuses more on spiritual level. While working life mainly focuses on material level. Due to the construction and usage of human, the building witnessed the changes and development of society, recorded history events and the economy and technical level at that time, reflected the era characteristics and values, which has the cultural significance and value. So its life span is not only 50 or 100 years. If the buildings are listed in the world cultural heritage and the national key cultural relics protection unit, it need pass legislation and all possible technical means, allow them to continue for one hundred or one thousand, such as the Forbidden City, temple of heaven; And more buildings are not included in the list of protection. The building itself is humble, but has the humanistic value extremely, or through the use functional change can stimulate vitality prolonging working and cultural life, at the same time, achieves the goal of development.

\section{Commercial life of the building}

The commercial life of buildings was limited in the scope of working life. For example, owners of shops, restaurants changed, buildings must be greatly modified and decorated both inside and outside. Then the commercial life of building can only lasted a few months of a few years or even more than ten years. The cycle depends on the needs of the business activities. But in the local estate development activities, commercial life of buildings is from the decline to renaissance, from old to new and death. The life of the building is not considering the structure life, working life and cultural life, and depending on the commercial interests. Driving by commercial interests and competent personnel to pursue "achievements", some buildings with safe structure, higher use value and even different degree of cultural value cultural significance, are declared the end of their lifespan in a sound, while its rest life also has certain economic value, environmental value, social value and spiritual value.

\section{Influence factors on building life}

\section{Poor quality of construction results in short building life}

House, as a finished product, involves planning, design, construction, supervision and civil air defense, health and other relevant departments in the process, so it should take these sectors linked together. As long as any one link is perfunctory, it is difficult to assure the quality of the whole 
building. Such as the museum of science and technology in Beijing, it is built when the Asian games was held. But by 2005 , more than $85 \%$ of the floor and wall has been well penetrated and cracked, bearing steel beam fractured, which existed significant security hidden danger. However the building has won the "special Luban jiang ". It exposed the contractor's responsibility for quality is not enough, also exposed construction quality control for the relevant departments is not strict, otherwise, there will not be awarded to such a project with serious problem. Taking Jilin province as an example, in the early 70s and 80s, the province only had limited design and construction units, state-owned, then the building in both the design and construction conformed to the laws and regulations and technical specification, rarely had quality problem. After the $90 \mathrm{~s}$, the province has more than 400 design units, the majority of which were private, the mess "whoever can design, whoever can construct" appeared. Construction quality began to decline since then. Although things have been improved after consolidation, but due to unreasonable design, the construction shoddy, cut corners and lack of the late maintenance and repair of buildings, construction quality will also be affected. Expert said, the reason of 53\% on short building life in China is quality.

\section{Unreasonable urban planning and design results in short building life}

Urban planning has no prospective, urban renewal is frequent.

The industrial policy of local government in a phase is often "short-sighted". It often stayed to solve temporary difficulties, not fully considered the future and long-term development. As many low-rise residential buildings in the early 50s and 60s, were demolished in the $1980 \mathrm{~s}$, and were changed for multi-storey residence. In the late 1990s and new century, many multi-storey residence built in the early 70s and 80s were removed for high-rise residence. Yuan Qifeng, a professor in ZhongShan University, said that during the past 27 years, china went out of the rapid urban construction development road with "compression" type, covered for 100 years in the developed countries.

Urban planning has no scientificity, some local leaders engage in unrealistic image projects

Construction of the great leap forward and improper view of achievement, leads to impetuous style in the architecture field. Some local leaders always hope to change the cities as short as possible, don't pay attention to the quality and the effect on the urban construction. They just pursue speed and the surface image. For example, parts of urban image projects, due to the pursuit of the achievement of his tenure, make planning, design, and construction simultaneously. So a lot of projects may be short-lived buildings. Impure motivation and decision-making errors are the biggest waste.

\section{Bad urban planning and management}

In recent years, due to many demolition cases such as adjusting planning and broadening the streets, some reinforced concrete high-rise residence of only more than 20 years had also been removed because of overpass or commercial development. A number of buildings were broken down not due to quality but the unreasonable planning, structure, or old city reconstruction, and so on. If planners and designers' vision put away and make a scientific, reasonable planning and design, we would not lead to so many buildings "ephemeral".

\section{The building using attitude and way is not reasonable}

It is common to break open a shop and brutally decorate in China. This brings some hidden troubles to houses in the future. Experts pointed out that the immunity of brick-and-cement structure is very low, usually looks very strong, but inside has holes. "Even if put off wall fill again back, it is infeasible because of structural damage is irreversible."

\section{Countermeasures for extending the building life}

Extending the building life, we need start from new-constructed and stock housing.

\section{For new-constructed house, strengthen the planning, design and construction}

As buildings involved the planning, design, construction, management and other stages, each stage is linked together and affects each other. If any one stage goes wrong, it will affect the quality of construction, thus affect building life. 


\section{Strictly abide by the design specification and consider the regional overall development during the planning and design stage}

The planning and design of a building should be scientific and forward-looking to make it compatible with the regional overall development. As monomer architecture, design units need design in strict accordance with the design specifications, pay attention to rationality. Perform according to 《architectural design standard》. If project can't reach the standard, relevant departments should be no acceptance. Housing design should not only solve the quality problem, more to solve the performance problem, including temperature, air, lighting, ventilation, environmental protection, intelligent, and so on. Within the real estate industry, collusion between designer and materials dealer, or the developers is common. Money goes into the pockets of the designer, while the house into the state and the people, left a lingering pain. The Japanese government issues a series of measures, regulates that shoddy construction designers will be in prison for three years, maximum fine lines also increases to 3 million yen.

In strict accordance with the design and strengthen the construction management during the construction stage

Construction unit should strictly in accordance with the design drawings. Illegal construction will trigger a very strict punishment system. Construction materials used in the construction also need be checked and tested strictly according to design requirements. In the industry, some real estate development company use "cramps" ways to reduce costs in the process of construction projects, and cut corners phenomenon is very common. Government departments should manage strictly, and give tougher penalties.

Strengthen repair and maintenance of the buildings during the management and maintenance stage

Although design period in the western developed countries is closed to in China, but because western countries pay attention to maintenance and maintenance, the building life prolongs. China also has a lot of ancient buildings with long life, such as the Zhaozhou bridge, the Great Wall, the Forbidden City, etc. The reason of long life for these ancient buildings is mainly to spend big bucks to repair and maintenance at any time.

\section{For stock housing, strengthen the daily maintenance and repair}

For the moment, "check-up plan" on resident need be started as soon as possible, and then trim, repair and reconstruct as soon as possible according to the specific "physical examination report".

Incorporate in the local government plan for renovation and activate the public maintenance fund as soon as possible. In 2012, Hong Kong had introduced mandatory inspection building program, which clearly defined responsibility both private owners and the government: the government supervision can't be absent; private owners need be responsible for maintenance and repair as part of the building property right person.

\section{Perfect the regulatory measures and intensify supervision}

Improve admittance threshold of construction industry, set up quality responsibility system

Eliminate the low level design and construction team, establish fair competition system under an orderly market economy condition, improve and strictly enforce the housing quality responsibility investigation. In terms of some houses collapsed abnormal, strict accountability need be started after the investigation. On April 4, 2014, Dacheng road in Fenghua, Ningbo, Zhejiang province, a 5 floors residential building collapsed, which was only built for 17-18 years. Although the relevant developers had been revoked business license, but it still existed on the civil liability.

\section{Put value on building life and strengthen construction quality monitoring}

The average life of British building is 132 years, which can be attributed to NHBC. NHBC, "national housing building committee", is a non-profit organization. Its mission is to help the home builders to build new housing that can fit the need of homeowners. As the independent management and standard positioning organization of building construction industry, it was founded in the $1930 \mathrm{~s}$, whose members include consumer group, home builders, developers, mortgage loan business, the specialized agencies and other groups. Functions of NHBC are primarily registration for home 
builders and developers; to determine the construction standards; construction inspection; to provide quality guarantee and insurance for new housing.

Building life in china gets less attention than western countries. China has no standard to evaluate the durability of building. At present, China's building quality monitoring mainly still stay on the current situation monitoring of the building, and less concerned about the quality surveillance of the residence.

\section{Strengthen the supervision of government departments for engineering construction}

Management mode should change the past administrative command for laws and regulations. Facts showed that some practice, damage to engineering quality, such as violation of construction procedures, bidding in, triangular debts, and improperly shorten the construction period, were caused by some local party and government department leaders.

\section{References}

[1]Experts said that new buildings life in China didn't exceed 30 years, less than a quarter of British. xinhuanet $2014,4,7$

[2]Zhao Jida: Extend the working life of existing buildings structure [J]. Housing Industry, 2010(7)

[3]Ge Chenghua: Discussion on some problems concerning the working life of construction project [J]. Anhui Architecture, 2012 (4)

[4]Luo Qianrong: Related theory and development trend of building life in our country [J]. Co-operative Economy\& Science, 2011 (12) 